\title{
KEDUDUKAN HUTAN ADAT PASCA PUTUSAN MAHKAMAH KONSTITUSI NOMOR 35/PUU-IX/2012 DAN HUBUNGANNYA DENGAN PENGELOLAAN HUTAN DI INDONESIA
}

\author{
Bambang Wiyono \\ Pegawai Kementerian Lingkungan Hidup \\ e-mail: bambangwiyono@gmail.com
}

\begin{abstract}
Abstrak-Pengakuan atas hutan adat dapat ditangguhkan apabila tidak sesuai dengan perkembangan masyarakat dan bertentangan dengan prinsip Negara Kesatuan Republik Indonesia, maka hutan adat harus dilihat sebagai hutan negara. Kebijakan yang tertuang dalam peraturan perundang-undangan seringkali dalam implementasinya tidak sesuai dengan harapan masyarakat, bahkan dapat menimbulkan permasalahan di masyarakat, kebijakan tersebut tertuang dalam ketentuan Pasal 1 angka 6 dan Pasal 5 UndangUndang Nomor 41 Tahun 1999 tentang Kehutanan, dan atas Putusan Mahkamah Konstitusi Nomor 35/PUU-IX/2012 dinyatakan bertentangan dengan UUD 1945 dan oleh karenanya ketentuan tersebut tidak mempunyai kekuatan hukum mengikat, dengan demikian kedudukan hutan adat setelah adanya Putusan Mahkamah Konstitusi Nomor 35/PUU-IX/2012 sebagai hutan yang berada di dalam wilayah masyarakat hukum adat dengan tetap memperhatikan hak masyarakat hukum adat sepanjang kenyataannya masih ada dan diakui keberadaannya, serta tidak bertentangan dengan kepentingan nasional sesuai dengan perkembangan masyarakat dan prinsip Negara Kesatuan Republik Indonesia yang diatur dalam undang-undang. Kebijakan Pemerintah yang seharusnya dalam pengaturan hutan adat pasca Putusan Mahkamah Konstitusi Nomor 35/PUUIX/2012 adalah sebagai berikut: Melakukan penetapan wilayah yang merupakan hutan adat terpisah dari pengelolaan hutan negara, dan ditunjuk sebagai daerah penyangga kawasan hutan negara; melakukan pengaturan masyarakat hukum adat melalui pemberdayaan masyarakat sesuai kearifan lokal; jenis tumbuh-tumbuhan dan satwa liar yang dilindungi tetap dalam pengelolaan pemerintah kecuali untuk kepentingan acara adat; melakukan pembinaan dan bimbingan kepada masyarakat hukum adat tentang tata cara pemanfaatan hutan adat sesuai kearifan lokal.
\end{abstract}

\section{Kata Kunci: Hutan Adat, Putusan Mahkamah Konstitusi, Pengelolaan Hutan.}

Abstract- Recognition of indigenous forests can be suspended if they are not in accordance with the development of society and is contrary to the principle of the Unitary Republic of Indonesia, then the law should be seen as a state forest. Based on the results of research, it shows that the policy in the legislation, the implementation is not in accordance with the expectations of society, and can even cause problems in the community. The policy is stated as stipulated in Article 1 point 6 and Article 5 of Act Number 41 Year 1999 on Forestry, and upon the Constitutional Court Decision Number 35/PUU-IX/2012, was declared contrary to the 1945 Constitution. Therefore these provisions do not have binding legal force, thus the position of indigenous forests in Indonesia after the Constitutional Court Decision Number 35/PUU -IX/2012, as forests those are within a customary community with regard to rights of indigenous people throughout the reality, is still there and acknowledged, and not contrary to the national interest in accordance with the development of society and the principles of the Unitary Republic of Indonesia stipulated in law. Government policies those should be put in a customary forest regulation post Constitutional Court Decision Number 35/PUUIX/2012 are as follows : Perform a customary forests zoning that is separated from 
management of state forests, and designated as state forests' buffer zone; make arrangements customary law communities through community empowerment appropriates to local wisdom; species of plants and wildlife remain in the management of government except for the sake of custom events; conduct training and guidance to the customary law society about the procedure of indigenous customary forest utilization appropriates to local wisdom.

Keywords: Traditional Forest, the Constitutional Court's Decision, Forest Management.

\section{A. PENDAHULUAN}

Hutan sebagai karunia dan amanah Tuhan Yang Maha Esa yang dianugerahkan kepada Bangsa Indonesia, merupakan kekayaan alam yang tak ternilai harganya yang wajib disyukuri. Karunia yang diberikanNya, dipandang sebagai amanah, karenanya hutan harus diurus dan dimanfaatkan dengan akhlak mulia dalam rangka beribadah sebagai perwujudan rasa syukur kepada Allah Yang Maha Esa (Undang-Undang Nomor 41 Tahun 1999 tentang Kehutanan).

Setelah setengah abad, pada tahun 2015 luas hutan Indonesia menurun menjadi sekitar 120 juta hektar dari 180 juta hektar luas Indonesia (Direktur Jenderal Planologi Kehutanan, 2015), sehingga pemerintah berkewajiban untuk menguasai, melindungi, dan mengelola kawasan hutan sesuai dengan amanah Undang-Undang
Dasar Negara Repubik Indonesia Tahun 1945 (Herwin Simbolon, 2011). Kebijakan pengelolaan sumber daya hutan di Indonesia mengacu pada ideologi penguasaan dan pemanfaatan sumber daya alam sebagaimana tercermin dalam Pasal 33 ayat (3) UUD 1945 yang menegaskan, bahwa: "Bumi, dan air dan kekayaan alam yang terkandung di dalamnya dikuasai oleh negara dan dipergunakan untuk sebesar-besar kemakmuran rakyat". Berdasarkan ketentuan tersebut dapat disimpulkan, bahwa negara menguasai kekayaan alam yang terkandung di dalamnya, namun penguasaan itu dibatasi oleh harus dipergunakan untuk sebesarbesarnya kemakmuran rakyat (Muchsan, 1981:9).

Kesatuan masyarakat hukum adat telah ada dan telah mendiami pertiwi Indonesia sejak jaman dahulu kala dan pada saat itu masyarakat masih memeluk paham animisme atau 
kepercayaan terhadap alam, karena pada saat itu masyarakat sangat menghargai dan menjunjung tinggi keberadaan dan keadaan alam tersebut. Kesatuan masyarakat hukum adat atau dapat dikatakan masyarakat adat hidup di Negara Indonesia berdasarkan 3 (tiga) faktor, yaitu keturunan (genologis), faktor wilayah (teritorial) dan faktor keturunanwilayah (genologis-teritorial) (Nico Ngani, 2000:21).

Dalam faktor wilayah kediaman (teritorial) masyarakat hukum adat mempunyai hak penuh terhadap segala sumber daya alamnya yang berada di dalamnya yang berupa hutan adat maupun perkebunanperkebunan dari setiap individu masyarakat adat tersebut. Keberadaan hutan pada lingkup wilayah masyarakat hukum adat merupakan sebuah potensi yang sangat signifikan, karena pada masa-masa para leluhur terdahulu sangat menggantungkan hidupnya terhadap hutan tersebut.

Hutan yang dikelola masyarakat hukum adat tersebut dimasukkan ke dalam pengertian hutan negara sebagai konsekwensi adanya hak menguasai oleh negara sebagai organisasi kekuasaan seluruh rakyat pada tingkatan yang tertinggi sesuai dengan prinsip Negara Kesatuan Republik Indonesia. Walaupun hutan adat dimasukkan dalam pengertian hutan negara, tetapi tidak meniadakan hak-hak masyarakat hukum adat, sepanjang masyarakat hukum adat pada kenyataannya masih ada dan diakui keberadaannya untuk melakukan kegiatan pengelolaan hutan.

$$
\text { Undang-Undang Nomor } 41
$$

Tahun 1999 tentang Kehutanan yang lahir pada awal reformasi tersebut menyisakan permasalahan yang cukup mendasar, yaitu keberadaan masyarakat hukum adat yang dicurigai akan melakukan serangkaian aktivitas di dalam dan di luar kawasan hutan yang berpotensi merusak kelestarian atau fungsi ekosistem hutan dan kemungkinan masyarakat hukum adat akan melakukan penggerogotan terhadap hutan-hutan yang masih dinyatakan sebagai kawasan hutan negara (Undang-Undang Nomor 41 Tahun 1999 tentang Kehutanan, Pasal angka 4). 
Kedua asumsi kecurigaan tersebut menjadikan pengaturan pengakuan terhadap masyarakat hukum adat bersifat bersyarat dan pengakuan terhadap masyarakat hukum adat dipenuhi dengan imbuhan-imbuhan yang kalau dikalkulasikan justru mementahkan kehendak awalnya untuk mengakui keberadaan masyarakat hukum adat, hal tersebut cukup jelas dirumuskan dalam beberapa ketentuan, baik dalam pasal maupun pada ayat dalam Undang-Undang Nomor 41 Tahun 1999 tentang Kehutanan.

Dalam perkembangannya pasca terbentuknya Negara Kesatuan Republik Indonesia, pengakuan dan perlindungan yang diberikan oleh negara terhadap hak-hak masyarakat hukum adat mengalami degradasi. Berbagai kebijakan yang dilakukan oleh pemerintah dengan orientasi pertumbuhan ekonomi dan modernisasi menjadi salah satu faktor, terpinggirkannya hak-hak masyarakat hukum adat, misalnya kebijakan pemerintah yang mengeluarkan izin-izin hak pengelolaan hutan kepada swasta telah mengakibatkan penebangan hutan tanpa perencanaan matang dan tanpa memikirkan dampaknya untuk generasi berikutnya. Masyarakat hukum adat dengan berbagai keterbatasannya tersingkir dari hutan dan hal ini menyebabkan menurunnya tingkat kesejahteraannya.

Seandainya pemerintah selalu konsisten untuk menjamin atas hak masyarakat atas hutan adat, tentunya pasti tidak akan ada peraturan perundang-undangan yang bertentangan dengan konstitusi, karena konstitusi sudah sejak dulu menjaminnya. Putusan Mahkamah Konstitusi Nomor 35/PUU-X/2012 yang menggangap Pasal 1 angka 6, Pasal 4 ayat (3), Pasal 5 ayat (1), ayat (2), ayat (3) Undang-Undang Nomor 41 Tahun 1999 tentang Kehutanan bertentangan dengan konstitusi menunjukkan adanya penyimpangan dalam mengatur hutan adat. Dalam perspektif Hak Asasi Manusia, Pasal 1 angka 6, Pasal 4 ayat (3), Pasal 5 ayat (1), ayat (2), ayat (3) UndangUndang Nomor 41 Tahun 1999 tentang Kehutanan mempunyai semangat perlindungan terhadap hak masyarakat hukum adat atas hutan adat yang bersifat derogable 
represive. Sementara itu, Putusan Mahkamah Konstitusi Nomor 35/PUU-X/2012 mempunyai semangat perlindungan yang bersifat derogable progressive (Faiq Tobroni, 2013:461).

Menyimak Putusan Mahkamah Konstitusi Nomor 35/PUU-X/2012 terdapat 3 (tiga) hal, yaitu:

1. Mahkamah Konstitusi menghapus frasa "negara" dalam Pasal 1 angka 6, sehingga bunyi Pasal 1 angka 6 menjadi "Hutan adat adalah hutan yang berada dalam wilayah masyarakat hukum adat".

2. Mahkamah Konstitusi menafsirkan bersyarat Pasal 5 ayat (1) sepanjang tidak dimaknai "hutan negara sebagaimana dimaksud pada ayat (1) huruf a, tidak termasuk hutan adat" dan menghapus frasa "dan ayat (2)" dalam pasal 5 ayat (3), sehingga semakin mengokohkan hutan adat bukan hutan negara.

3. Mahkamah Konstitusi menyatakan Pasal 4 ayat (3) Undang-Undang Nomor 41 Tahun 1999 Tentang Kehutanan bertentangan dengan Undang-Undang Dasar 1945, dan tidak mempunyai kekuatan hukum mengikat sepanjang tidak dimaknai "Penguasaan hutan oleh negara tetap memperhatikan hak masyarakat hukum adat, sepanjang masih ada dan diakui keberadaannya sesuai dengan perkembangan masyarakat dan prinsip Negara Kesatuan Republik Indonesia yang diatur dalam undang-undang.
Dari uraian di atas, dapat dirumuskan permasalah pokok, bagaimana kedudukan hutan adat pasca Putusan Mahkamah Konstitusi Nomor 35/PUU-IX/2012, dan bagaimana seharusnya kebijakan pemerintah dalam pengaturan hutan adat pasca Putusan Mahkamah Konstitusi Nomor 35/PUU-IX/2012 dan hubungannya dengan pengelolaan hutan di Indonesia.

\section{B. HASIL DAN PEMBAHASAN}

Pembukaan UUD 1945 terdiri dari beberapa alinea yang masingmasing memiliki kerangka pemikiran yang luas dan mendalam (Otje Salman S. dan Anthon F. Susanto, 2004:156). Oleh karena itu, sebelum mengkaji lebih jauh, terlebih dahulu memaparkan beberapa alinea Pembukaan UUD 1945 tersebut. Alinea-alinea Pembukaan UUD 1945 yang disoroti memiliki relevansi dengan "Negara Hukum Kesejahteran" yang digunakan dalam menulis makalah ini adalah alinea kedua (adil dan makmur), alinea ketiga (berkat rahmat Allah/semangat spirutual), dan alinea keempat terkait dengan hukum yang memberikan 
perlindungan terhadap kehutanan di Indonesia yang sejalan dengan tujuan pembangunan nasional Indonesia sebagaimana difilosofikan dalam Pembukaan UUD 1945 pada alinea keempat.

\section{Pasal 33 ayat (3) UUD 1945} sebagai landasan konstitusional yang mewajibkan agar bumi, air dan kekayaan alam yang terkandung di dalamnya dikuasai oleh negara dan dipergunakan untuk sebesar-besarnya kemakmuran rakyat, maka penyelenggaraan kehutanan senantiasa mengandung jiwa dan semangat kerakyatan, keadilan, dan berkelanjutan. Pasal 33 ayat (3) Undang-Undang Dasar 1945 memberikan "hak penguasaan" kepada negara atas seluruh sumber daya alam Indonesia dan memberikan "kewajiban kepada negara" untuk menggunakannya bagi sebesarbesarnya kemakmuran rakyat. Penguasaan hutan oleh negara bukan merupakan pemilikan, tetapi negara memberikan wewenang kepada pemerintah untuk:

1. Mengatur dan mengurus segala sesuatu yang berkaitan dengan hutan, kawasan hutan dan hasil hutan.
2. Menetapkan kawasan hutan dan atau mengubah status kawasan hutan.

3. Mengatur dan menetapkan hubungan hukum antara orang dengan hutan atau kawasan hutan dan hasil hutan.

4. Mengatur perbuatan hukum mengenai kehutanan.

Kementerian Lingkungan

Hidup dan Kehutanan sadar betul akan tujuan penyelenggaraan kehutanan yang diamanatkan Pasal 3 Undang-Undang Nomor 41 Tahun 1999 sebagai berikut:

“...Penyelenggaraan kehutanan yang bertujuan untuk sebesarbesar kemakmuran rakyat yang berkeadilan dan berkelanjutan dengan menjamin keberadaan hutan dengan luasan yang cukup dan sebaran yang proposional; mengoptimalkan aneka fungsi hutan yang meliputi fungsi konservasi, fungsi lindung, dan fungsi produksi untuk mencapai manfaat lingkungan, sosial, budaya, dan ekonomi, yang seimbang dan lestari; meningkatkan daya dukung daerah alran sungai; meningkatkan kemampuan untuk mengembankan kapasitas dan pemberdayaan masyarakat secara partisipatif, berkeadilan, dan wawasan lingkungan sehingga mampu menciptakan ketahanan sosial dan ekonomi; dan menjamin distribusi manfaat yang berkeadilan dan berkelanjutan". 
Pengakuan terhadap masyarakat hukum adat dan hak-haknya mendapat landasan hukum di dalam UUD 1945 sebelum perubahan UUD 1945 dapat dilihat dalam penjelasan Pasal 18 UUD 1945 yang dirumuskan sebagai berikut:

“...Dalam teritorial Negara Indonesia terdapat lebih kurang $250 \quad$ Zelfbesturende landschappen dan voklsgemeenschappen, seperti desa di Jawa dan Bali, nagari di Minangkabau, dusun dan marga di Palembang, dan sebagainya. Daerah-daerah itu mempunyai susunan asli, dan oleh karenanya dapat dianggap sebagai daerah yang bersifat istimewa".

Setelah perubahan UUD 1945, mengenai masyarakat hukum adat dari segi pengakuan, penghormatan, dan perlindungannya dapat berpedoman pada Pasal 18B ayat (2) sebagai berikut:

“...Negara mengakui dan menghormati kesatuan-kesatuan masyarakat hukum adat beserta hak-hak tradisionalnya sepanjang masih hidup dan sesuai dengan perkembangan masyarakat dan prinsip negara Kesatuan Republik Indonesia yang diatur dalam undangundang".
Selanjutnya diperkuat dalam Pasal 28I ayat (3) UUD 1945:

"...Identitas budaya dan hak
masyarakat tradisional di
hormati selaras dengan
perkembangan zaman dan
peradaban".

Dalam Pasal ini diakui adanya kebudayaan sebuah kelompok masyarakat, walaupun belum jelas masyarakat mana yang dimaksud. Ketika Pasal ini dihubungankan dengan Pasal 18B ayat (2), maka dapat ditarik kesimpulan, bahwa yang dimaksud dengan masyarakat tradisional dalam Pasal 28I ayat (3) adalah masyarakat hukum adat dengan hak tradisionalnya.

Berdasarkan perumusan Pasal 18B ayat (2) UUD 1945 terdapat 4 (empat) syarat bagi eksistensi hukum adat sebagai berikut:

1. "Sepanjang masih hidup". Persyaratan tersebut perlu diteliti dengan seksama dan hati-hati, tidak hanya menggunakan tolok ukur kuantitatif rasional, melainkan lebih dengan empati dan partisipasi. Kita tidak sematamata melakukan pengamatan dari luar, melainkan juga dari dalam dengan menyelami perasaan masyarakat setempat. Metodologi yang digunakan adalah partisipatif.

2. "Sesuai dengan perkembangan masyarakat". Syarat tersebut tidak ditafsirkan dari segi ekonomi dan 
politik, melainkan dari kaca mata masyarakat setempat. Penafsiran dari kedua segi tersebut mengandung risiko untuk memaksakan (imposing) kepentingan raksasa atas nama "perkembangan masyarakat". Masyarakat akan sangat sulit menghindari dari penetrasi teknologi dan itu akan menimbulkan dinamika di dalam masyarakat tersebut.

3. "Sesuai dengan prinsip Negara Kesatuan Republik Indonesia". Negara Indonesia dan masyarakat lokal adalah satu kesatuan tubuh. Keduanya tidak boleh dihadapkan secara dikhotomis atau hitam putih, melainkan dipahami bahwa masyarakat lokal atau adat adalah bagian dari dan darah daging dari Negara Kesatuan Republik Indonesia itu sendiri. Penelitian yang dilakukan berdasarkan paradigma tersebut akan berbeda daripada yang melihat Negara Kesatuan Republik Indonesia dan masyarakat adat sebagai dua entitas yang berbeda dan berhadaphadapan. Metode yang digunakan akan lebih cocok apabila digunakan paradigma tersebut.

4. "Diatur dalam undang-undang". Dengan perumusan Pasal 18 ayat (2) dan Pasal 28I ayat (3) dengan kata-kata pada anak kalimat, "sepanjang masih hidup sesuai dengan perkembangan masyarakat", prinsip Negara Kesatuan Republik Indonesia diatur dalam undang-undang dan selaras dengan perkembangan zaman dan peradaban. Perumusan ini sudah tentu dapat menimbulkan aneka penafsiran, karena itu perlu direvisi.
Berdasarkan rumusan Pasal

18B ayat (2) UUD 1945, jika dikaitkan dengan Pasal 62 ayat (2) Undang-Undang Nomor 39 Tahun 1999, bahwa: "Identitas budaya masyarakat hukum adat termasuk hak atas tanah ulayat dilindungi, selaras dengan perkembangan zaman". Hal ini dalam Pasal 67 ayat (1) UndangUndang Nomor 41 Tahun 1999 juga dirumuskan, sebagai berikut:

"Masyarakat hukum adat sepanjang menurut kenyataannya masih ada dan diakui keberadaannya berhak:

a. Melakukan pemungutan hasil hutan untuk pemenuhan kebutuhan hisup sehari-hari masyarakat adat yang bersangkutan.

b. Melakukan kegiatan pengelolaan hutan berdasarkan hukum adat yang berlaku dan tidak bertentangan dengan undang-undang.

c. Mendapatkan pemberdayaan dalam rangka meningkatkan kesejahteraannya".

Dengan demikian, hukum adat dalam posisinya sebagai bagian dari hukum nasional berarti hukum adat sebagai pelengkap, artinya berlakunya hukum adat sangat tergantung pada peraturan perundang-undangan, yakni undang-undang lebih superior dari 
hukum adat. Hal ini dapat dilihat sebagai implikasi penerapan hak menguasai negara sebagaimana tercantum dalam Pasal 33 ayat (3) UUD 1945, dan penerapannya sejajar dengan politik pembangunan yang sentralistik. Berdasarkan konstitusi Indonesia mengenai hak penguasaan negara diatur berlandaskan Pasal 33 ayat (3) UUD 1945 tersebut, yakni mengatur dan menetapkan penguasaan bumi, air, dan kekayaan alam yang terkandung di dalamnya dikuasai oleh negara yang pengaturan lebih lanjut diatur dalam UndangUndang.

Undang-Undang Nomor 41 Tahun 1999 tentang Kehutanan telah digugat oleh kelompok masyarakat hukum adat, yaitu Aliansi Masyarakat Adat Nusantara (AMAN), Kesatuan Masyarakat Hukum Adat Kenegerian Kuntu Kabupaten Kampar Provinsi Riau, dan Kesatuan Masyarakat Hukum Adat Kasepuhan Cisitu Kabupaten Lebak Provinsi Banten dengan mengajukan gugatan uji materi pasal-pasal tersebut ke Mahkamah Konstitusi yang telah memiliki kekuatan hukum tetap (final dan mengikat) dengan mengabulkan gugatan pemohon sebagian dalam Keputusan Mahkamah Konstitusi Nomor 35/PUU-X/2012, sehingga hutan adat mendapat kedudukan yang kuat kembali.

Mahkamah Konstitusi Sebagai penjaga norma konstitusi (constitutional guardian) dari Negara Kesatuan Republik Indonesia, telah menegaskan bahwa kebijakan sejak diundangkannya Undang-Undang Nomor 41 Tahun 1999 tentang Kehutanan telah salah secara konstitusional memasukkan hutan adat ke dalam kategori hutan negara, dan segala praktik pemerintah yang berdasar pada kesalahan itu telah bertentangan dengan konstitusi UUD 1945 yang telah diamandemen, termasuk Pasal 18B yang berbunyi, bahwa:

"Negara mengakui dan menghormati kesatuan-kesatuan masyarakat hukum adat beserta hak-hak tradisionalnya sepanjang masih hidup dan sesuai dengan perkembangan masyarakat dan prinsip Negara Kesatuan Republik Indonesia, yang diatur dalam undangundang".

Menurut Mahkamah Konstitusi, dalam ketentuan konstitusional tersebut, terdapat satu hal penting dan 
fundamental dalam lalu-lintas hubungan hukum. Hal penting dan fundamental tersebut adalah masyarakat hukum adat tersebut secara konstitusional diakui dan dihormati sebagai "penyandang hak" yang dengan demikian tentunya dapat pula dibebani kewajiban. Dengan demikian, masyarakat hukum adat adalah subjek hukum. Sebagai subjek hukum di dalam suatu masyarakat yang telah bernegara maka masyarakat hukum adat haruslah mendapat perhatian sebagaimana subjek hukum yang lain ketika hukum hendak mengatur, terutama mengatur dalam rangka pengalokasian dan pengelolaan sumber-sumber kehidupan.

Mahkamah Konstitusi meralat penggunaan/penyalahgunaan konsep "hak menguasai negara" yang sangat kuat demikian itu (Ismatul Hakim, 2014:101). Dalam suatu kesempatan lain, Ahmad Sodiki, salah satu dari hakim Mahkamah Konstitusi yang menjadi tulang punggung dari putusan-putusan progresif atas perkara-perkara judicial review undang-undang agraria/sumber daya alam di Mahkamah Konstitusi, mengemukakan pandangannya

(Putusan mahkamah Konstitusi Nomor 35/PUU-X/2012) sebagai berikut:

"...jika dikaitkan dengan Pasal 33 ayat (3) UUD 1945 menjadi tugas negara bagaimana pengusahaan sumber daya alam yakni bumi, air dan kekayaan alam yang terkandung di dalamnya dimanfaatkan untuk sebesar-besar kemakmuran rakyat (secara adil dan merata). Hal itu tidak dapat dicapai dengan menegakkan hukum semata, karena ternyata hukum yang berkenaan dengan sumber daya alam mengandung cacat yang, jika ditegakkan, justru akan menimbulkan ketidakadilan sosial. Penegakan hukum sumber daya alam yang tidak adil akan mengancam eksistensi masyarakat hukum adat yang sangat rentan penggusuran oleh mereka yang mengatasnamakan atau izin dari negara".

Jadi, menurut Mahkamah Konstitusi, dalam putusannya atas perkara 35/PUU-X/2012 itu, tidak boleh terjadi lagi penggunaan alasan HMN yang sangat kuat itu yang berakibat penyangkalan status masyarakat hukum adat dalam Negara Kesatuan Republik Indonesia sebagai penyandang hak (rights bearer/rights holder) dan subjek hukum pemilik 
atas wilayah adatnya. Analisis atas putusan-putusan Mahkamah Konstitusi yang berkenaan dengan judicial review atas berbagai undangundang pertanahan dan sumber daya alam, Mahkamah Konstitusi telah menetapkan norma yang dimaksud dengan "konsep menguasai" sebagaimana dimaksudkan oleh Pasal 33 ayat (3) UUD 1945.

Pemerintah daerah mempunyai peran dalam penetapan keberadaan masyarakat hukum adat dalam rangka pengelolaan hutan adat. Langkahlangkah yang harus dilakukan pemerintah daerah dalam mendukung keberadaan hutan adat (Budi Riyanto, Tt:74), antara lain:

1. Inventarisasi daerah yang masih terdapat masyarakat hukum adat.

2. Melakukan pengkajian dan penelitian.

3. Menetapkan wilayah tertentu sebagai wilayah masyarakat hukum adat dalam bentuk peraturan daerah.

$$
\text { Selanjutnya penulis }
$$

memberikan kesimpulan atas Putusan Mahkamah Konstitusi Nomor 35/PUU-X/2012 sebagai berikut:

1. Hutan adat yang sebelumnya menjadi bagian dari hutan negara, berdasarkan Putusan Mahkamah
Konstitusi tersebut, hutan adat harus dimaknai sebagai hutan hak.

2. Hutan adat dimaknai sebagai hutan yang berada di dalam wilayah masyarakat hukum adat.

3. Penguasaan hutan oleh negara tetap memperhatikan hak masyarakat hukum adat, sepanjang masih hidup dan sesuai dengan perkembangan masyarakat dan prinsip Negara Kesatuan Republik Indonesia yang diatur dalam undang-undang.

4. Keberadaan masyarakat hukum adat harus diatur dalam undangundang, sepanjang undang-undang dimaksud belum terbentuk, maka pengukuhan dan hapusnya masyarakat hukum adat ditetapkan dengan peraturan daerah dapat dibenarkan, sepanjang peraturan tersebut menjamin kepastian hukum dan berkeadilan.

5. Putusan Mahkamah Konstitusi tersebut harus dimaknai, pemerintah menetapkan status hutan dan hutan adat dipertahankan sepanjang kenyataan masyarakat hukum adat yang bersangkutan masih ada dan diakui keberadaannya.

6. Apabila dalam perkembangannya masyarakat hutan adat tidak ada lagi, maka hak pengelolaan hutan adat dikembalikan kepada pemerintah dan status hutan adat kembali menjadi hutan negara.

Dengan keluarnya putusan

Mahkamah Konstitusi Nomor 35/PUU-X/2012 yang menguji Undang-Undang Nomor 41 Tahun 1999 tentang Kehutanan khususnya ketentuan Pasal 1 angka 6 dan Pasal 5 
telah memberikan kekuatan hukum atas kedudukan pengusaaan hutan adat oleh masyarakat hukum adat, sehingga keberadaan dan perlindungan penguasaan hutan adat dan masyarakat hukum adat mendapat tempat yang semakin kuat dan dengan Putusan tersebut telah menjadikan masyarakat adat setidaknya (Mia

\section{Siscawati, Sajogyo, 2013:5):}

1. Pengakuan masyarakat adat sebagai "penyandang hak" (rightsbearer), dan subjek hukum atas wilayah adatnya. Putusan Mahkamah Konstitusi perlu dimaknai sebagai pemulihan kewarganegaraan masyarakat adat.

2. Setelah Putusan Mahkamah Konstitusi atas perkara Nomor 35/ PUU-X/ 2012 itu, tantangan terbesar saat ini adalah mewujudkan ralat konsep pembangunan dan ralat kebijakan secara menyeluruh.

3. Putusan Mahkamah Konstitusi perlu dijadikan rujukan bagi perubahan mendasar dalam pengelolaan kekayaan alam dan sumber-sumber agraria lainnya.

Oleh karena itu, seharusnya pemerintah dan pemerintah daerah dalam rangka menindak lanjuti Putusan Mahkamah Konstitusi Nomor 35/ PUU-X/ 2012 dapat mengambil kebijakan yang seharusnya dilakukan yaitu:
1. Pembentukan tim yang khusus guna menyiapkan saran tindak Kementerian Kehutanan pasca putusan tersebut. Adapun tugas tim adalah sebagai berikut:

2. Mencermati materi putusan Mahkamah Konstitusi secara baik dan benar.

3. Penyusunan materi langkah tindak Kementerian Kehutanan pasca putusan Mahkamah Konstitusi.

4. Melakukan sosialisasi materi langkah tindak tersebut kepada jajaran Kementerian Kehutanan, baik di pusat maupun di daerah serta instansi terkait dan masyarakat.

5. Menyusun kembali draft Rancangan Peraturan Pemerintah tentang Pengelolaan Hutan Adat disesuaikan dengan putusan Mahkamah Konstitusi dengan tetap memperhatikan UndangUndang Nomor 41 Tahun 1999 dan Undang-Undang Nomor 5 Tahun 1990 bersama instansi terkait.

6. Bersama dengan tim dari Kementerian Dalam Negeri dan Badan Pertanahan Nasional untuk merumuskan Rancangan Peraturan Pemerintah tentang Pengakuan Masyarakat Hukum Adat dan juga membantu menyusun Raperda apabila dibutuhkan oleh Pemerintah Daerah tentang Pengukuhan Masyarakat Hukum Adat.

7. Kementerian Lingkungan Hidup dan Kehutanan hendaknya mempercepat pemberdayaan masyarakat melalui kebijakan sebagaimana diatur dalam Peraturan Pemerintah Nomor 6 Tahun 2007 tentang Tata Hutan 
dan Penyusunan Rencana Pengelolaan Hutan serta Pemanfaatan Hutan yang meliputi hutan desa, hutan kemasyarakatan, hutan tanaman rakyat, dan kemitraan. Apabila dalam peraturan pelaksanaannya masih dirasakan banyak hambatan, maka perlu deregulasi kebijakan pemberdayaan masyarakat tersebut.

8. Khusus untuk pengelolaan kawasan suaka alam dan kawasan pelestarian alam diperlukan langkah konkrit penguatan kawasan dengan segera melengkapi rencana pengelolaan kawasan dan penataan kawasan serta penetapan daerah penyangga melalui Peraturan Daerah penyangga.

9. Selain hal itu, Kementerian Lingkungan Hidup dan Kehutanan juga mempersiapkan Naskah Akademik sebagai pendamping terkait usulan Rancangan Undang-Undang Inisiatif DPR tentang Pengakuan Masyarakat Hukum Adat dan Hak Tradisionalnya yang dimaksudkan untuk menyatukan langkah dan pandangan pemerintah, baik secara ilmiah, teknis, maupun yuridis.

Berdasarkan uraian di atas, pasca Putusan Mahkamah Konstitusi Nomor 35/PUU-X/2012 selain upaya di atas, berimplikasi pada hal-hal sebagai bertikut:

1. Terdapat beberapa upaya di kalangan masyarakat untuk secara fisik memperjelas batas-batas wilayah adat di lapangan dan mengambil alih tanah-tanah adat yang di atasnya sudah diberikan izin kepada pihak ketiga. Sampai saat ini belum dapat dipastikan jumlah luasan hutan adat, bahkan Data dari Aliansi Masyarakat Adat Nusantara (AMAN) sampai November 2012, telah mengidentifikasi 2.4 juta hektar wilayah adat yang terdiri dari 265 peta wilayah adat.

2. Muncul berbagai isu hukum yang belum dapat terjawab dengan konstruksi aturan yang ada saat ini, antara lain, mekanisme identifikasi masyarakat hukum adat, batasan kewenangan masyarakat hukum adat di dalam mengelola hutan adat, sejauh mana masyarakat hukum adat dapat mengalihkan/menyewakan hak atas hutan adat kepada pihak lain dan dengan mekanisme seperti apa, sejauh mana kewenangan masyarakat hukum adat untuk dapat mengalihkan hutan adat menjadi non-hutan, bagaimana bentuk formal pengakuan negara atas hutan adat yang dimiliki oleh masyarakat hukum adat.

3. Munculnya potensi konflik sosial akibat konsep wilayah adat/hutan adat yang memiliki dasar hukum yang jelas.

Di samping itu, harus disikapi pula secara arif dan bijaksana dan segera dilakukan langkah-langkah kongrit untuk implementasinya secara sungguh-sungguh. Kesungguhan pemerintah tersebut dapat ditunjukkan dengan segera 
menyusun kebijakan pada tataran policy level dan institutional level sampai dengan operational level, sehingga dapat menjadi acuan dan segera dilaksanakan di daerah. Dalam penyusunan kebijakan operasional hendaknya lebih akomodif dan partisipatif, sehingga dapat dilaksanakan dan memenuhi rasa keadilan masyarakat. Apabila hal tersebut dapat direalisasikan, maka panggilan jiwa Pasal 33 ayat (3) UUD 1945 dapat terwujud dan cita-cita good forestry governance dapat terlaksana, yaitu masyarakat sejahtera dan hutan lestari.

\section{C.SIMPULAN}

1. Kebijakan yang tidak berorientasi kepada kebutuhan masyarakat dapat menimbulkan permasalahan dalam pelaksanaannya, kebijakan tersebut tertuang dalam ketentuan Pasal 1 angka 6, Pasal 4 Ayat (3) dan Pasal 5 Undang-Undang Nomor 41 Tahun 1999 tentang Kehutanan, dan atas Putusan Mahkamah Konstitusi Nomor 35/PUUIX/2012, ketentuan tersebut dinyatakan bertentangan dengan UUD 1945 dan oleh karenanya ketentuan tersebut tidak mempunyai kekuatan hukum mengikat, dengan demikian kedudukan hutan adat di Indonesia setelah adanya Putusan Mahkamah Konstitusi Nomor 35/PUU-IX/2012 sebagai hutan yang berada di dalam wilayah masyarakat hukum adat dengan tetap memperhatikan hak masyarakat hukum adat sepanjang kenyataannya masih ada dan diakui keberadaannya, serta tidak bertentangan dengan kepentingan nasional sesuai dengan perkembangan masyarakat dan prinsip Negara Kesatuan Republik Indonesia yang diatur dalam undangundang.

2. Kebijakan Pemerintah yang seharusnya dalam pengaturan hutan adat pasca Putusan Mahkamah Konstitusi Nomor 35/PUU-IX/2012 adalah:

a. Melakukan penetapan wilayah yang merupakan hutan adat terpisah dari 
Bambang Wiyono, Kedudukan Hutan Adat Pasca Putusan Mahkamah...

pengelolaan hutan negara, dan ditunjuk sebagai daerah penyangga kawasan hutan negara.

b. Melakukan

pengaturan masyarakat hukum adat melalui pemberdayaan masyarakat sesuai kearifan lokal.

c. Jenis tumbuh-tumbuhan dan satwa liar yang dilindungi tetap dalam pengelolaan pemerintah kecuali untuk kepentingan acara adat.

d. Melakukan pembinaan dan bimbingan kepada masyarakat hukum adat tentang tata cara pemanfaatan hutan adat sesuai kearifan lokal.

\section{SARAN}

1. Mengingat Undang-Undang tentang Pengakuan dan Perlindungan Hak Masyarakat Hutan Adat belum diterbitkan, maka pengakuan Pemerintah Daerah dapat diminta untuk menginventarisir masyarakat hukum adat yang ada di wilayahnya sebelum menyusun
Perda tentang pengakuan masyarakat hukum adat dimaksud.

2. Menyelesaikan Rancangan Peraturan Pemerintah tentang Pengelolaan Hutan Adat yang muatan materinya mengakomodir Putusan Mahkamah Konstitusi Nomor 35/PUU-IX/2012, (lihat Draft RPP tentang Hutan Adat)..

3. Bersama dengan tim dari Kementerian Dalam Negeri dan Badan Pertanahan Nasional dan dari Sekretariat Negara untuk merumuskan Rancangan Peraturan Pemerintah Tentang Masyarakat Hukum Adat dan juga membantu penyusunan Rancangan Peraturan Daerah apabila dibutuhkan Pemerintah Daerah tentang pengukuhan Masyarakat Hukum Adat.

4. Kementerian Lingkungan Hidup dan Kehutanan mempercepat pemberdayaan masyarakat melalui kebijakan sebagaimana diatur dalam Peraturan Pemerintah Nomor 6 tahun 2007 serta perubahan yang meliputi: hutan desa, 
hutan kemasyarakatan, hutan tanaman rakyat dan kemitraan.

5. Agar pengakuan dan pengaturan kedudukan hutan adat dapat diterima masyarakat, maka perlu sosialisasi dan harmonisasi peraturan yang mengatur masalah hutan adat dan segera disusun peraturan pelaksanaan pada tingkat instsitusional level dan operasional level sehingga segera dapat diterapkan di masyarakat.

\section{DAFTAR PUSTAKA}

Budi Riyanto, Bunga Rampai Hukum Kehutanan dan Sumber Daya Alam : Menuju Smart Regulation, Lembaga Pengkajian Hukum Kehutanan dan Lingkungan, Bogor, Tanpa Tahun.

Direktur Jenderal Planologi Kehutanan, dalam paparan Rapat Kerja Kementerian Lingkungan Hidup dan Kehutanan, Maret 2015.

Faiq Tobroni, Menguatkan Hak Masyarakat Adat atas Hutan Adat (Studi Putusan MK Nomor 35/PUU-X/2012), Jurnal Konstitusi Volume 10
Nomor 3, Mahkamah Konstitusi, Jakarta, 2013.

Herwin Simbolon dalam keterangan ahli sidang Mahkamah Konstitusi, tanggal 21 September 2011.

Ismatul Hakim et.al., Hutan untuk Rakyat : Jalan Reformasi Agraria di Sektor Kehutanan, LKiS, Yogyakarta, 2014.

Mia Siscawati, Sajogyo, Tindak Lanjut Putusan MK Nomor 35, MRV dan Pemanfaatan CLAS Lite untuk Analisis Deforestasi Bali, Institute Pelatihan Awal REDD, Bali, 2013.

Muchsan, Hukum Administrasi Negara dan Peradilan, Administrasi Negara di Indonesia, Liberty, Jakarta, 1981.

Nico Ngani, Pekembangan Hukum Adat Indonesia, Pustaka Yustitia, Yogyakarta, 2000.

Otje Salman S. dan Anthon F. Susanto, Teori Hukum: Mengingat, Mengumpulkan, dan Membuka Kembali, Refika Aditama, Bandung, 2004.

Undang-Undang Nomor 41 Tahun 1999 tentang Kehutanan. 